\title{
Study of Biological Factors of Flying Fish (Decapterus Spp) Results of Purse Seine Ship Capacity in Waters of South Buton Regency, Southeast Sulawesi
}

\author{
Bahtiar Hamar $^{1 *}$, Aristi Dian Purnama Fitri ${ }^{2}$, Bambang Sulardiono ${ }^{2}$ \\ ${ }^{1}$ Master Student of Water Resource Management, Faculty of Fisheries and Marine Sciences, Diponegoro University, \\ Semarang \\ ${ }^{2}$ Teaching Staff of the Master of Water Resource Management, Faculty of Fisheries and Marine Sciences, Diponegoro \\ University Semarang, Jl. Prof. H. Soedarto, SH, Semarang 50275
}

\section{*Corresponding Author}

Bahtiar Hamar

\author{
Article History \\ Received: 03.03.2020 \\ Accepted: 15.03 .2020 \\ Published: 01.04.2020
}

\begin{abstract}
Flying Fish is an important fishery source in the tropics and sub-tropics because of its high economic value, so that exploitation continues to be carried out even some waters in Indonesia have experienced high fishing pressures. This study aims to identify the biological factors of Flying Fish (Decapterus spp) that catches purse seine in the waters of the South Buton Regency. The method of collecting data uses the method of observation (observation) of the catch of purse sein vessels every day for 3 (three) months. Analysis of growth parameters, mortality, length first captures, using RStudio software. From the analysis results obtained asymptotic length $(\mathrm{L} \infty)$ of $27.10 \mathrm{~cm}$ and the value of growth rate $(\mathrm{K})$ of 0.196 , to of,- 0471 . Total mortality was 0.311 , natural mortality was 0.257 , arrest mortality was 0.054, and the rate of exploitation was 0.175 . The growth rate is relatively slow with a $\mathrm{K}$ value of 0.196 . The exploitation rate value (E) has not exceeded the optimum value of 0.5 meaning that Flying Fish in South Buton waters is suspected to have a low exploitation rate and a high spawning potential. The length of the first gonad (Length of the first maturity) $(\mathrm{Lm})$ at $14.2 \mathrm{~cm}$, while the length of the first fish caught $(\mathrm{Lc})$ at $16.6 \mathrm{~cm}$, the optimal length (Lopt) of $18.3 \mathrm{~cm}$. This indicates that generally Flying Fish caught in South Buton waters have matured.
\end{abstract}

Keywords: Flying Fish, Growth, Mortality, Exploitation, RStudio.

\section{INTRODUCTION}

Marine fisheries resources which are essentially open and are not restricted to use based on the local administrative area, so that the Marine and Fisheries sector has different characteristics from other sectors. Utilization of marine and fisheries resources is expected to be developed through various marine and fisheries industries based on environmental sustainability and market-oriented because it is very strategic and makes fisheries one of the sub-sectors that can sustain the Indonesian economy [1].

Small pelagic fish resources that play a major role in the economic sector of fishermen in South Buton, one of which is Flying Fish (Decapterus spp). This is shown from the production of small pelagic fish, especially Flying Fish in South Buton Regency in 2015 amounted to 2,959 tons, in 2016 amounted to 2,141 tons, in 2107 amounted to 2,219 tons, 2018 amounted to 6,831 tons [2]. Based on data on the capture of Flying Fish in South Buton Regency from year to year shows fluctuating numbers, then a study is needed to determine the condition of the Flying Fish in South Buton Regency waters. If the demand for fish from outside continues to increase without any sustainable management it will have an impact on fish populations in Indonesia. In management information is needed that involves a study of population stock such as growth, mortality and exploitation rates.

Copyright @ 2020: This is an open-access article distributed under the terms of the Creative Commons Attribution license which permits unrestricted use, distribution, and reproduction in any medium for non commercial use (NonCommercial, or CC-BY-NC) provided the original author and source are credited. 
The purpose of this study is to examine the biological factors of Flying Fish in the transitional season based on growth rate, mortality, exploitation rate, size of the first gonad ripening, first caught and optimum size of Flying Fish in the waters of the South Buton Regency landed in Banabungi Village, Kadatua District.

The benefits of this study are as information about the biological factors of Flying Fish in South Buton, the results of this study are expected to be taken into consideration in the management of Flying Fish and as study material for further research.

\section{METHODS}

This research was conducted for three months, from May to July 2019, which at that time was the transition season I (May) and East Season (June and July), located in Banabungi Village, Kadatua District, South Buton Regency, which is fishing bases purse seine.

\section{Research Procedure}

This study uses primary data which is total length data (total length. The frequency of fish length data is obtained through measurements of the catches of mini purse sein vessels. The length of fish data collection is carried out on the ship every day.

\section{Data Analysis}

The observed fish population parameters are growth parameters, mortality and exploitation rate, the average length of fish first caught, the length of the first gonad ripe fish, optimum length. Estimation of fish growth, growth coefficient $(\mathrm{K})$, asymptotic length $(\mathrm{L} \infty)$ which is the maximum length of the fish is theoretically estimated using the ELEFAN SA method in RStudio software, while the theoretical age (t0) is estimated by the equation empirical Pauly [3] the equation can be seen as follows:

$$
\log \left(-t_{0}\right)=-0,3922-0,2752 \log (L \infty)-1,038(\log K)
$$

According to Sparre, et al. [4] that the values of L $\infty$, t0, and $\mathrm{K}$ can be used to estimate the growth parameters using the Von Bertalanffy growth formula as follows:

$$
\mathrm{Lt}=\mathrm{L} \infty\left(1-\mathrm{e}^{[-\mathrm{K}(\mathrm{t}-\mathrm{to})]}\right)
$$

Estimating the total mortality value $(Z)$ by using the catch converted curve length method (length converted catch curve) with the help of Rstudio Pauly software [3], Mildenberger et al. [5]. Estimation of exploitation rate (E) and capture mortality (F) can be calculated using formula [3], namely:

$$
\begin{aligned}
& Z=F+M \text { sehingga } \mathrm{F}=\mathrm{Z}-\mathrm{M} . \\
& \text { and } E=\frac{F}{Z} \ldots \ldots \ldots \ldots \ldots \ldots \ldots \ldots \ldots \ldots \ldots
\end{aligned}
$$

Estimation of the average length of the first caught fish (Lc) was calculated with the help of RStudio software [5]. Estimation of the optimal length (Lopt) using the Beverton equation [6], while the estimation of the length of the first ripe gonad fish (Lm) using the Froese and Binohlan [7] equations with the following equation:

$$
\begin{gathered}
\text { Lopt }=1.0421 * \log L \infty-0.2742 \ldots \\
\text { Log Lm }=0,8979 * \log L \infty-0,078 .
\end{gathered}
$$

\section{RESUlTS AND DisCUSSION}

\section{Growth Rate Parameter $\left(\mathrm{L}_{\infty}, \mathrm{K}\right.$, and $\left.\mathbf{t}_{\mathbf{0}}\right)$}

The results of the analysis of the estimation of growth parameters using the RStudio Software [5] are presented in table 1 . Based on the analysis of asymptotic length $(\mathrm{L} \infty)$ of $27.1 \mathrm{~cm}$ with a growth rate $(\mathrm{K})$ of $0.20 /$ year, while the value of t0 $-0.471 /$ year.

Table-1: Estimated values of Growth parameters $\left(\mathbf{L}_{\infty}, \mathbf{K}, \mathbf{t}_{\mathbf{0}}\right)$
\begin{tabular}{|l|l|}
\hline Parameter & Parameter Value \\
\hline Asymptotic Length $(\mathrm{L} \infty)(\mathrm{cm})$ & 27,1 \\
\hline Growth rate $(\mathrm{K})(\mathrm{cm})$ & 0,196 \\
\hline $\mathrm{t}_{0}$ & $-0,471$ \\
\hline
\end{tabular}

Based on the Von Bertalanffy equation [8], the Flying Fish growth equation is obtained. 
$\mathrm{Lt}=27,1\left(1-\exp { }^{[-0,196(1-0,471)]}\right)$

From the above equation, it can be assumed that the length of the age share, which can then be calculated as the Flying Fish age increase until it reaches its asymptotic. Based on these equations it can be seen that the rate of growth in South Buton waters is fast occurring at a young age and slower along with the age of the fish to reach its asymptotic length. This is in accordance with the opinion of Sparre and Venema [4] that the lower the growth coefficient (K), the longer the time needed for fish to reach its asymptotic length $(\mathrm{L} \infty)$ and vice versa. According to Effendi [9] that the growth rate of each species is very dependent on the age of the species itself so that in general the growth rate of fish becomes slow with increasing the age of the fish. This is because old fish generally lack food, this is because the food they get is used for movement and maintenance of the body.

Table-2: Growth parameters of Flying Fish (Decapterus spp) in various research locations

\begin{tabular}{|l|l|c|c|c|}
\hline \multirow{2}{*}{ Researcher } & \multirow{2}{*}{ Location } & \multicolumn{3}{c|}{ Growth Parameters } \\
\cline { 3 - 5 } & & $\mathbf{L}_{\infty}(\mathbf{c m})$ & K $\left._{(\text {Year }}{ }^{-\mathbf{1}}\right)$ & $\mathbf{t}_{\mathbf{0}}$ (Year) \\
\hline Suwarni (2015) & Gulf of Bone & 30,6 & 0,33 & $-0,03$ \\
\hline Rohniadita (2016) & Sunda Strait & 27,8 & 0,31 & $-0,29$ \\
\hline Alnanda (2017) & Malacca Strait & 24,2 & 1.29 & -0.46 \\
\hline Research Result (2019) & $\begin{array}{l}\text { South Buton } \\
\text { Waters }\end{array}$ & 27,1 & 0,196 & $-0,47$ \\
\hline
\end{tabular}

Based on table 2. above it can be seen that research conducted in different waters has different $\mathrm{L} \infty$ and $\mathrm{K}$ values. This difference in value can be caused by several external and internal factors. According to Sudirman and Karim [10] that differences in fish length in a different waters can be caused by environmental differences in a waters such as food availability and habitat.

\section{Mortality and Exploitation Rate}

Mortality and Flying Fish exploitation rate in the waters of South Buton Regency are presented in Table 3. Based on the estimated value of the growth parameters, it can be calculated to obtain the estimated value of the death rate of the total death rate $(\mathrm{Z})$, the capture death rate $(\mathrm{F})$, and the Natural death rate $(\mathrm{M})$. For estimating the rate of utilization or exploitation rate $(\mathrm{E})$, the calculation is carried out by dividing the capture death value $(\mathrm{F})$ to the total death value $(\mathrm{Z})$ in order to obtain the exploitation rate value $(\mathrm{E})$.

Table-3: Estimating values of the Mortality and Exploitation Rate Parameters

\begin{tabular}{|l|l|}
\hline \multicolumn{1}{|c|}{ Parameter } & Parameter Value \\
\hline Total Mortality $(\mathrm{Z})$ & 0,311 \\
\hline Natural Mortality $(\mathrm{M})$ & 0,257 \\
\hline Capture mortality $(\mathrm{F})$ & 0,054 \\
\hline Utilization rate $(\mathrm{E})$ & 0,175 \\
\hline
\end{tabular}

Based on table 3, above the total mortality rate of $0.311 /$ year with a natural mortality rate of $0.257 /$ year, while the capture mortality rate of 0.054 /year, the capture mortality value $(\mathrm{F})$ is 0.054 smaller than the natural mortality value (M) of 0.257. It can be assumed that the mortality of fish in South Buton waters is dominated by natural deaths, the natural mortality rate of $0.257 /$ year in this study is smaller than the results of research conducted by Rosmini [11] in 2008 in the waters of Luwu Regency at 0.61 per month, and research Suwarni, et al. [12] conducted in the bay bone of $0.37 /$ year. At the capture mortality rate in South Buton of 0.054 where this value is smaller than the results of Suwarni, et al. [12] research in Bone Bay which is 2.07, this can be indicated that the estimated intensity of Flying Fish capture in South Buton waters is lower than in the waters of the bay of Bone. This can be seen from the rate of exploitation in South Buton waters which is 0.175 smaller than the results of Suwarni research [12] where the rate of exploitation in the waters of the Gulf of Bone is 0.85 . High natural death rates can also be influenced by several factors including the egg and larval phases, environmental factors such as salinity and temperature, predation, hunger, physiological changes, and density of a fish population $[13,14]$.

The rate of exploitation in South Buton waters is still very low, where the value is still below the optimum exploitation limit value, which means that fishing activities can still be increased. According to Rochet \& Trenkel [15] that the value of the rate of exploitation is suggested as an indicator to measure capture pressure with a target reference point that is equal to 0.5 .

The low mortality and exploitation rate obtained during research in South Buton waters can be caused because in May to July is a famine season. Based on interviews with fishermen that from May to July it is a famine season and 
waves are hard, where many fishermen choose not to go to sea due to reduced catches. So many fishermen choose not to go to sea to reduce their losses during fishing operations because of the very high cost of fuel procurement. This is in accordance with Fauzi [16] that the Flying Fish famine season occurs in the eastern season, namely June to July and the transition season 2 in October to November, then the West season in December to February.

\section{Average Fish Length First Caught (Lc), Estimated Length of Fish First Time Gonad (Lm), and Optimal Length Estimated Fish}

For the average length of first caught fish (Lc) in South Buton Waters are presented in table 4. According to Froese and Binohlan [7] that by using the L $\infty$ and Lopt values obtained from the growth graph equation and the $\mathrm{M}$ values. These three values have Empirical relationships when the data needed to estimate the length of the first ripe gonad (Lm) such as frequency, temperature, and sex are not available. Lopt estimation requires a natural mortality value (M) and a K value of. Flying Fish long frequency chart (Decapterus spp) can be seen in Figure 1.

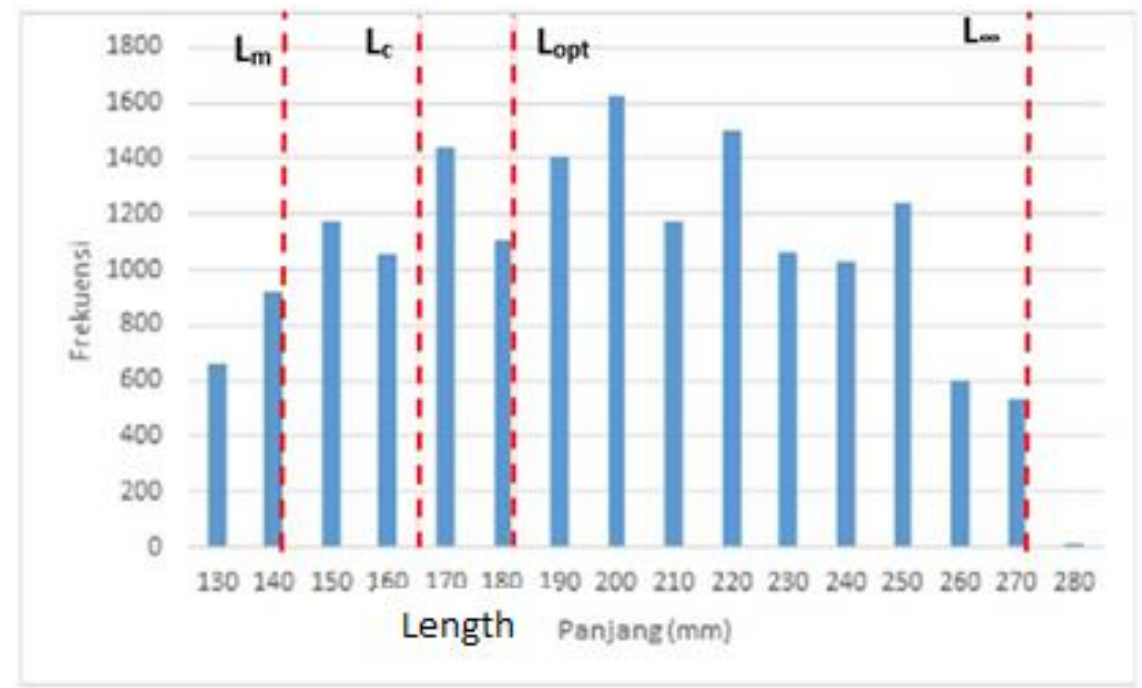

Fig-1: Graph of Flying Fish long frequency distribution

Table-4: The parameters of the length of the fish when the gonads first cooked, the length of the fish that was first caught and the optimal length $\left(\mathbf{L}_{\mathbf{m}}, \mathbf{L}_{\mathbf{5 0}}, \mathbf{L}_{\mathbf{o p t}}\right)$

\begin{tabular}{|l|l|}
\hline \multicolumn{1}{|c|}{ Parameter } & Parameter Value \\
\hline $\mathrm{L}_{50}$ or $\mathrm{L}_{\mathrm{c}}(\mathrm{cm})$ & 16,6 \\
\hline $\mathrm{L}_{\mathrm{m}}(\mathrm{cm})$ & 14,2 \\
\hline $\mathrm{L}_{\mathrm{opt}}(\mathrm{cm})$ & 18,3 \\
\hline
\end{tabular}

Based on table 4, it can be seen that Flying Fish in South Buton waters were caught after experiencing a mature gonad $(\mathrm{Lc}>\mathrm{Lm})$, the graph can be seen in Figure 2. This shows that as many as $50 \%$ of the fish were caught in size after the gonads mature and are large in size. The condition of Lc>Lm indicates the chance of Flying Fish to breed is relatively high. The length of the first time the fish was caught (Lc) in this study was the size of $16.6 \mathrm{~cm}$. The length of the first time the Flying Fish was caught was greater than the length value of the first time the gonad was cooked, which was 14.2. The length of the first-cooked gonad ( $\mathrm{Lm}$ ) fish in this study is smaller than the length of the first-captured fish (Lc) and the optimal length of the fish (Lopt). This indicates that generally Flying Fish caught in South Buton waters are mature and have been large. 


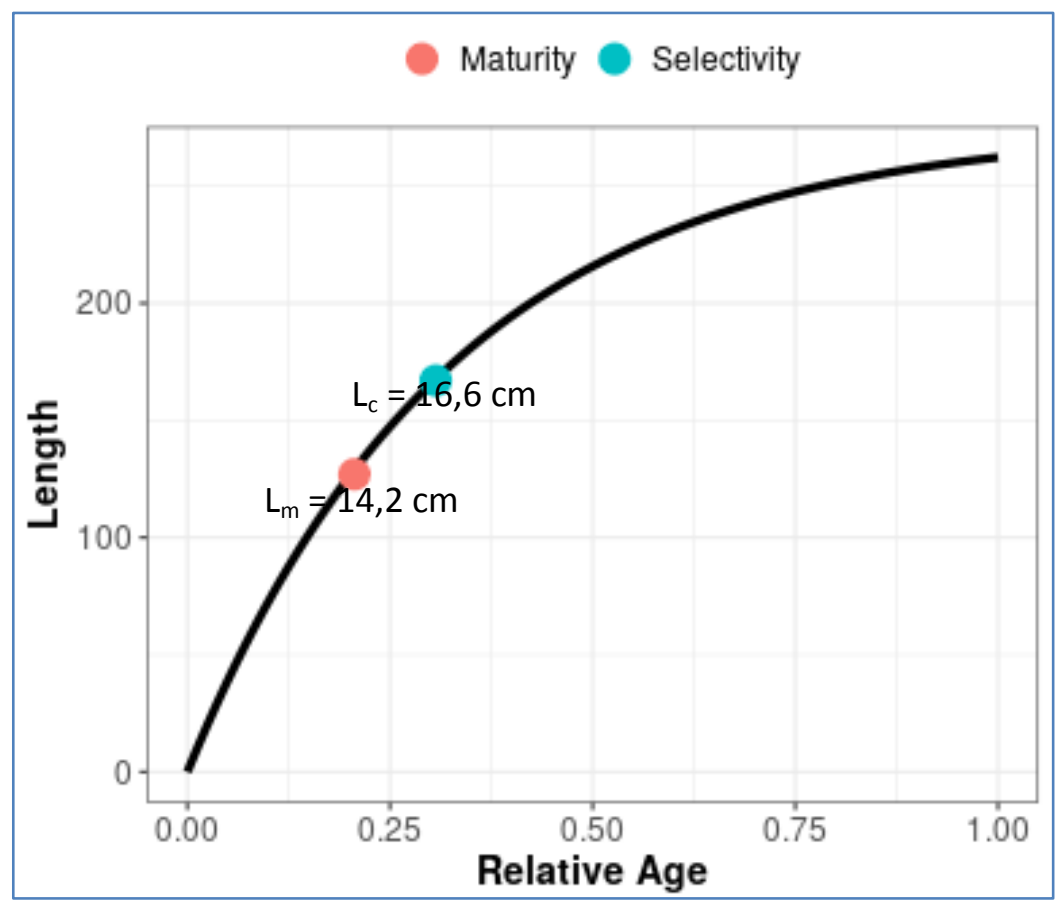

Fig-2: Graphic of first-time gonad fish being cooked and first-caught fish

The first measure of gonad maturity obtained in this study was not much different from the results of the study of Prihatini, et al. [17] and Dahlan, et al. [18], where Prihatini's research results obtained the size of D. macrosoma first mature sex (Lm) 14, $5-15.1 \mathrm{~cm}$, while Dahlan research results obtained size D. Macrosoma first mature gonads are 12.8 $\mathrm{cm}$ females and $14.2 \mathrm{~cm}$, males. The results of research in Mangaluru waters, India by Ashwini et al. [19] that the size of the first ripe gonad Flying Fish D. ruselli is $16 \mathrm{~cm}$ male fish and $18 \mathrm{~cm}$ male. The difference in the Lm size of several types of Flying Fish can be caused by water conditions, physiological and geographical location of each region. According to Dahlan et al. [18] that the geographical location and condition of water can influence the age and size of the fish when the gonads first mature, so that the size of the first gonad ripens between the same species and other species will vary. According to Sulistiono, et al. [20] that the factors affecting a species first mature in the gonads are differences in age, species, size, sex and also the spawning grounds of the fish species.

\section{CONCLUSION}

Flying Fish growth is slow to reach its Asymptotic length $(\mathrm{L} \infty)$ of $27.1 \mathrm{~cm}, \mathrm{~K}$ value of $0.196 /$ year, and to-value of -0.471 /year. The natural mortality rate $(\mathrm{M})$ of 0.257 is greater when compared to the capture mortality rate $(\mathrm{F})$ of 0.054 so it can be seen that the greater fish mortality is caused by natural death, this can be seen from the very low rate of exploitation that is equal to 0.175 which is still below the optimum value of 0.5 . Flying Fish caught at the first time the gonad is cooked $(\mathrm{Lm})$ is $14.2 \mathrm{~cm}$ and first caught $(\mathrm{Lc})$ is $16.6 \mathrm{~cm}$, and the optimal length (Lopt) is $18.3 \mathrm{~cm}$, this indicates that generally Flying Fish caught in South Buton waters have grown up and have been large.

\section{SUGGESTION}

Based on the results of research into the study of the parameters of the Flying Fish population, it is hoped that the management of Flying Fish by increasing capture at a sustainable level. As well as the need for further research on ecological and biological aspects of fish in-depth to be able to strengthen the results of research.

\section{REFERENCES}

1. Sujiyanto, S. (2015). Strategi Kebijakan Pengelolaan Nelayan Andon Sebagai Upaya Pelestarian Sumberdaya Ikan di Kota Tegal. Buletin Ilmiah Marina Sosial Ekonomi Kelautan dan Perikanan, 1(1), 29-39.

2. South Buton Regency Maritime and Fisheries Service. (2019). Laporan Statistik Perikanan Kabupaten Buton Selatan. DKP. Kabupaten Buton Selatan.

3. Pauly, D. (1984). On the interrelationships between natural mortality, growth parameters, and mean environmental temperature in 175 fish stocks. ICES Journal of Marine Science, 39(2), 175-192.

4. Sparre, P., \& Venema, S.C. (1998). Introduction to tropical fish stock assessment. Part 1: Manual. FAO Fisheries Technical Paper. No. 306.1 Rev. 2, 407 pp. Rome: FAO. 
5. Mildenberger, T. K., Taylor, M. H., \& Wolff, M. (2017). TropFishR: An R Package for Fisheries Analysis with Length-Frequency Data. Methods in Ecology and Evolution, 8(11), 1520-7.

6. Beverton, R. J. H. (1992). Patterns of reproductive strategy parameters in some marine teleost fishes. Journal of Fish Biology 41(Suppl. B) 137-160

7. Froese, R., Binohlan, C. (2000). Empirical relationships to estimate asymptotic length, length at first maturity and length at maximum yield per recruit in fishes, with a simple method to evaluate length frequency data. Journal of Fish Biology, 56, 758-773.

8. Von Bertalanffy, L. (1934). Untersuchungen über die Gesetzlichkeit des Wachstums. Wilhelm Roux'Archiv für Entwicklungsmechanik der Organismen, 131(4), 613-652.

9. Effendie, M. I. (2002). Biologi Perikanan. Yogyakarta: Yayasan Pustaka Nusatama.

10. Sudirman, H., Karim, M. Y. (2008). Ikan Kerapu, Eksploitasi, Manajemen dan Budidaya. P. 129. Yogyakarta: Liberty.

11. Rosmini. (2008). Tingkat Eksploitasi dan Dinamika Populasi Ikan Layang (Decapterus spp.) Di sekitar Perairan Kabupaten Luwu. Thesis, Fisheries Resource Utilization Study Program. Hasanuddin University.

12. Suwarni, S., Triesnati, J., Umar, M. T., Nur, M., \& Hikmasari, H. (2015). Pendugaan Beberapa Parameter Dinamika Populasi Ikan Layang (Decapterus Macrosoma, Bleeker 1841) Di Perairan Teluk Bone, Sulawesi Selatan. Jurnal Administrasi dan Kebijakan Kesehatan Indonesia, 25(1), 106040.

13. Jørgensen, C., \& Holt, R. E. (2013). Natural mortality: its ecology, how it shapes fish life histories, and why it may be increased by fishing. Journal of Sea Research, 75, 8-18.

14. Nash, R. D., \& Geffen, A. J. (2012). Mortality through the early life-history of fish: What can we learn from European plaice (Pleuronectes platessa L.)?. Journal of Marine Systems, 93, 58-68.

15. Rochet, M. J., \& Trenkel, V. M. (2003). Which community indicators can measure the impact of fishing? A review and proposals. Canadian Journal of Fisheries and Aquatic Sciences, 60(1), 86-99.

16. Fauzi, M. (2018). Memburu Ikan Layang di Laut Banda. Badan Riset Dan Sumber Daya Manusia Kelautan dan Perikanan. Available from: https://kkp.go.id/brsdm/artikel/4766-memburu-layang-di-laut-banda accessed on March 10, 2020.

17. Prihartini, A., Anggoro, S., \& Asriyanto, A. (2007). Analisis Tampilan Biologis Ikan Layang (Decapterus sp) Hasil Tangkapan Purse Seine Yang Didaratkan Di Ppn Pekalongan Biological Performance Analysis of Layang (Decapterus spp) From The Purse Seine Fishery At The Ppn Pekalongan Landing Place. Jurnal Pasir Laut, 3(1), 6175.

18. Dahlan, M. A., Omar, S. B. A., Tresnati, J., Nur, M., \& Umar, M. T. (2016). Beberapa Aspek Reproduksi Ikan Layang Deles (Decapterus macrosoma Bleeker, 1841) yang Tertangkap dengan Bagan Perahu di Perairan Kabupaten Barru, Sulawesi Selatan. Jurnal IPTEKS Pemanfaatan Sumberdaya Perikanan, 2(3).

19. Ashwini, L. S., Benakappa, H. N., Anjanayappa., \& Akshay, L. (2016). Food and Feeding Habits of the Indian SCAD, Decapterus russelli (Ruppell, 1830) from Mangaluru Coast Internasional. Journal of Engineering Science and Computing 6(6): 7389-7393.

20. Sulistiono, S. K., \& Ernawati, Y. (2009). Aspek reproduksi ikan lidah, Cynoglossus lingua HB 1822 di Perairan Ujung Pangkah Jawa Timur. Jurnal Iktiologi Indonesia, 9(2), 175-185. 